\title{
DESCRIPTION OF STUDENTS LEARNING MOTIVATION TOWARDS THE USE OF PHET SIMULATION IN PHYSICS ONLINE LEARNING IN TERMS OF SELF-EFFICACY AND ANXIETY LEVELS
}

\author{
Ilham Eka Prasetya, Muhammad Yusuf, and Trisnawaty Junus Buhungo* \\ Physics Education Study Program, Faculty of Mathematics and Sciences, State University of Gorontalo, \\ Gorontalo, Indonesia \\ *Email: trisnawaty.buhungo@ung.ac.id
}

Accepted: January 03, 2022. Approved: January 09, 2022. Published: January 15, 2022

\begin{abstract}
The study aims to describe students' motivation to use PhET Simulation in online learning physics in class XI Science at SMA Terpadu Wira Bhakti Gorontalo regarding self-efficacy and anxiety levels. This type of research is descriptive qualitative. The research subjects were nine class grade eleventh IPA 1 SMA Terpadu Wira Bhakti Gorontalo with high, medium, and low academic abilities. Data collection techniques using observation, questionnaires, and interviews. The data analysis technique used descriptive statistical analysis and qualitative analysis, including data reduction, data presentation, and conclusion drawing/data verification. The results of the research on student learning motivation towards the use of PhET Simulation in online learning physics showed that based on the assessment on the level of self-efficacy and anxiety is categorized as very high. Students with high $(\mathrm{H})$ and moderate (M) academic abilities had high learning motivation very high category. In contrast, students with the low academic ability (L) have a high category of learning motivation. In conclusion, students become motivated in learning because of the use of PhET Simulation in online learning physics class XI IPA SMA Terpadu Wira Bhakti Gorontalo in terms of self-efficacy. Student anxiety is categorized as very high.
\end{abstract}

Keywords: Student Motivation, PhET Simulation, Self-efficacy, Anxiety, Online Learning

\section{INTRODUCTION}

The application of online learning as a form of effort to overcome the spread of Covid-19 in Indonesia is a form of innovation in learning activities. Changes in students' consumptive power towards technology, which was only a secondary need, have now turned into a primary requirement. The implementation of online learning refers to using online application platforms to assist the teaching and learning process in enabling the performance of distance learning [1].

The application of bold learning has advantages and disadvantages [2]. Implementing online learning can make learning flexible, meaning that it is constrained by time and place to learn [3] and can increase student independence in learning [4]. While the weakness of the application of online learning causes student learning activities to be ineffective, not all parents of students can buy data or mobile phones, and the provision of learning materials is weak [5]. However, online learning application also causes other problems, such as what happened in online learning physics in class XI IPA SMA Terpadu Wira Bhakti Gorontalo.

Physics online learning in class XI IPA Terpadu Wira Bhakti Gorontalo supported by applications Microsoft Teams and WhatsApp in online learning. Based on information from the physics subject teacher concerned, student motivation in studying physics continues to experience degradation because students are bored with online learning. The decrease in students' learning motivation can be observed from students who tend to be passive in the learning process. Students only listen to the delivery of material from the teacher without responding to the delivery of the material provided. When the teacher asks the material that has been delivered to see the level of students' understanding, only a few students are willing to respond. The rest do not respond to questions from the teacher. The teacher said that the conditions of learning physics in class XI IPA are very different from the conditions that occur during face-to-face physics learning.

The teacher then made efforts to make students re-motivated in learning, namely bringing up virtual experimental activities using PhET Simulation in the learning process. PhET Simulation is a virtual laboratory developed by a team from the University of Colorado, USA. PhET can display a form of interactive simulation on science concept materials that allows for virtual practicum activities [6]. PhET was developed to assist students in understanding physics concepts visually by using dynamic graphics that can explicitly bring to life the visual and conceptual models used by expert physicists [7]. The teacher hopes that using PhET Simulation in online learning of physics in class XI IPA, SMA Terpadu Wira Bhakti Gorontalo can motivate students to learn physics again.

Learning motivation is all forms of encouragement given to someone to be more enthusiastic about learning to achieve better [8]. Learning motivation is needed as a driving force in students' learning needs [9]. If a student is motivated in learning, students will show good behavior such as diligently and tenaciously carrying out study activities, which continuously increases students' enthusiasm for learning even for a long time [10]. Six 
indicators can be used to see students' learning motivation: intrinsic motivation, extrinsic motivation, personal goals indicators, self-determination indicators, self-efficacy indicators, and anxiety [11]. However, this study is interested in examining learning motivation based on student self-efficacy and the level of students in the online learning process of physics in class XI IPA SMA Terpadu Wira Bhakti Gorontalo on the use of PhET Simulation. Efficacy is related to students' beliefs about their abilities in realizing success for their actions [12]. At the same time, anxiety is defined as a feeling of fear of something that is not clear to a person [13], which can affect the quality of learning motivation [14].

Based on the background described, the researchers conducted a study to describe students' motivation to use PhET Simulation in online learning physics in class XI Science at SMA Terpadu Wira Bhakti Gorontalo in terms of self-efficacy and anxiety levels. This research is expected to produce an overview of students' learning motivation towards using PhET Simulation in online learning physics in class XI IPA SMA Terpadu Wira Bhakti Gorontalo. It can be used as material for consideration by the physics teacher concerned to continue using PhET Simulation in the learning process. Online or replace it with several other learning innovations that can increase students' motivation to learn physics online.

\section{RESEARCH METHODS}

This research was conducted at the SMA Terpadu Wira Bhakti Gorontalo in the even semester of the 2020/2021 academic year. The research method used in this research is descriptive qualitative research. Determination of research subjects was carried out purposively with the snowball sampling technique, namely at first choosing a small number of research subjects who could provide data in accordance with the research objectives. Then from the data have determined other research subjects. The data research objectives so that the number of research subjects becomes large until the research data is saturated [15]. Thus the issues in this study were nine students from 23 students of class XI IPA 1 at SMA Terpadu Wira Bhakti Gorontalo consisting of 3 students with a high academic ability $(\mathrm{H})$, three students with a moderate academic ability (M), and three students with a low intellectual ability (L). Each group of students with high, medium, and low academic abilities, each consisting of 3 students, has shown data saturation, so there is no need to add subjects again. Qualitative research data is considered saturated when the research data are valid. The validity of the data in this study used triangulation techniques, namely checking data from the same source with different methods [16]. The main instrument in this study was the researcher himself. Besides that, other instruments were used in this study, namely observation, questionnaire sheets, and interviews. Researchers carry out triangulation techniques by verifying the data from the questionnaire with the data from observations and interviews to see the validity of the data obtained in the study so that the data obtained can be verified. The data analysis technique used descriptive statistical analysis and qualitative analysis.

Descriptors to describe motivation based on a review of students' self-efficacy levels used in this study are a) students believe they can be the best in doing physics experiments on PhET Simulation; b) students are confident that they can operate PhET Simulation; c) students believe it can improve their knowledge and skills with physics experiments on PhET Simulation; d) students are confident in presenting the results of their experiments, and e) students believe in the experimental results they get.

Descriptors to describe motivation based on a review of students' anxiety levels used in this study were: a) students did physics experiments on PhET Simulation without feeling nervous; b) students do not panic when asked to show the experiment they are doing; c) students do not panic if they have problems doing physics experiments on PhET Simulation; d) students remain calm if other students are faster in completing physics experiments in PhET Simulation; and e) students are not afraid to express their opinion in the discussion of experimental results.

The questionnaire in this study consisted of 10 statements composed of 5 reports relating to students' self-efficacy levels and five statements relating to students' anxiety levels. The assessment of the questionnaire sheet in this study used a Likert scale with a rating scale of 1-4. Based on the total score of the questionnaire obtained by the students in the questionnaire, the category level of student learning motivation was determined, using the categorization norm [17] in Table 2.

Table 2. Categorization Norms of Student Learning Motivation

\begin{tabular}{cc}
\hline Scoring Criteria & Category \\
\hline$X$ item $\leq \tilde{x}+1,5 \sigma$ & Very High \\
$\tilde{x}+0,5 \sigma<X$ item $\leq \tilde{x}+1,5 \sigma$ & High \\
$\tilde{x}-0,5 \sigma<X$ item $\leq \tilde{x}+0,5 \sigma$ & Medium \\
$\tilde{x}-1,5 \sigma<X$ item $\leq \tilde{x}-0,5 \sigma$ & Low \\
$\tilde{x}-1,5 \sigma \leq X$ item & Very Low \\
\hline
\end{tabular}

Table 3. Categorization of Student Learning Motivation

\begin{tabular}{cc}
\hline Scoring Criteria & Category \\
\hline$>16,25$ & Very High \\
$13,75-16,25$ & High \\
$11,25-13,74$ & Medium \\
$8,75-11,24$ & Low \\
$<8,75$ & Very Low \\
\hline
\end{tabular}

Based on the categorization norm [17], calculations were carried out to find the criteria for the range of scores to determine the category of student 
motivation. Determination of the categorization of student learning motivation on each indicator in this study can be seen in Table 3 .

\section{RESULTS AND DISCUSSION}

Description of students' learning motivation towards the use of PhET Simulation in terms of self-efficacy

Self-efficacy in students refers to the degree of confidence that students have in all their efforts in the learning process at school. A person with a high level of self-efficacy does not give up easily and is persistent in doing his study assignments. He has confidence in himself to be increasingly motivated to complete learning tasks and take responsibility for it [18].

The student learning motivation questionnaire results on the use of PhET Simulation in physics teaching in class XI IPA SMA Terpadu Wira Bhakti Gorontalo in terms of students' self-efficacy levels are presented in Table 4.

Table 4. Results of Student Learning Motivation Questionnaire in terms of Self-Efficacy

\begin{tabular}{cccc}
\hline No. & Subject & Score & Category \\
\hline 1 & H1 & 20 & Very High \\
2 & H2 & 18 & Very High \\
3 & H3 & 20 & Very High \\
4 & M1 & 17 & Very High \\
5 & M2 & 18 & Very High \\
6 & M3 & 17 & Very High \\
7 & L1 & 14 & High \\
8 & L2 & 14 & High \\
\hline 9 & L3 & 16 & High \\
\hline \multicolumn{7}{c}{ Average } & 17,1 & Very Hight \\
\hline
\end{tabular}

Based on Table 4 , it can be seen that the results of the student learning motivation questionnaire with high academic ability $(\mathrm{H} 1, \mathrm{H} 2$, and H3) in terms of self-efficacy are categorized as very high. Student learning motivation with moderate academic ability (M1, M2, and M3) in terms of selfefficacy is categorized as very high. The learning motivation of students with a low academic ability (L1, L2, and L3) in terms of self-efficacy is categorized as high. Thus, based on the results of a review of self-efficacy. It is known that students become motivated to learn physics because of the use of PhET Simulation in online learning physics in class XI IPA SMA Terpadu Wira Bhakti Gorontalo with a very high level. The results of this questionnaire were then verified with the results of observations of learning activities and interviews through technical triangulation.

The data verification of students with a high academic ability $(\mathrm{H})$ questionnaire results using data from observations of learning activities and interview results through technical triangulation shows that students with high academic abilities $(\mathrm{H})$. It can be the best in physics experiments using PhET Simulation. I believe they can operate PhET well and am confident that they can improve their knowledge and skills in conducting physics experiments in PhET Simulation. In addition, students with a high academic ability $(\mathrm{H})$ are also confident in presenting the results of their experiments' results because they are confident in the experimental results they have managed to get.

The data verification of the questionnaire results of students with a moderate academic ability (M) using data from observations of learning activities and interviews through technical triangulation shows that students with moderate academic abilities (M). It can be the best in physics experiments using PhET Simulation. Students can operate PhET well and confidently improve their knowledge and skills in conducting physics experiments in PhET Simulation. In addition, students with a moderate academic ability (M) are also confident in presenting the results of their experiments' results because they are confident in the experimental results they have managed to get.

The data verification of the questionnaire results of students with a low academic ability (L) using data from observations of learning activities and interview results through technical triangulation showed that students with low academic abilities (L). Students could operate PhET well and believed they could improve their knowledge and skills in doing physics experiments on PhET Simulation. In addition, students with low academic ability (L) are also confident in presenting the results of their experiments, because they believe in the experimental results they have succeeded in getting. However students with low academic ability (L) are not sure if they can be the best at doing physics experiments on PhET Simulation.

\section{Description of students' learning motivation towards the use of PhET Simulation in terms of anxiety}

Anxiety is a psychological condition that is experienced by almost everyone when faced with troublesome problems or events and the results are unknown [19]. Anxiety is inversely proportional to learning motivation. The higher the anxiety level, the learning motivation is in a low category, and conversely lower the anxiety level, the learning motivation is in the high category [13].

The student learning motivation questionnaire results on the use of PhET Simulation in physics learning in class XI IPA SMA Terpadu Wira Bhakti Gorontalo in terms of student anxiety are presented in Table 5.

Based on Table 5, it can be seen that the results of the questionnaire on students' learning motivation with high academic ability $(\mathrm{H} 1, \mathrm{H} 2$, and H3) in terms of anxiety are categorized as very high. Students' learning motivation with a moderate academic ability (M1, M2, and M3) in terms of anxiety is categorized as very high. The learning motivation of students with low academic ability (L1, 
L2, and L3) in terms of anxiety is categorized as high. Thus, based on the results, students become motivated in learning physics because of the use of PhET Simulation in online physics learning in class XI IPA SMA Terpadu Wira Bhakti Gorontalo with a very high level of learning motivation. The results of this questionnaire were then verified with the results of observations of learning activities and interviews through technical triangulation.

Table 5. Results of Student Learning Motivation Questionnaire in terms of anxiety

\begin{tabular}{cccc}
\hline No. & Subject & Score & Category \\
\hline 1 & H1 & 18 & Very High \\
2 & H2 & 18 & Very High \\
3 & H3 & 20 & Very High \\
4 & M1 & 17 & Very High \\
5 & M2 & 17 & Very High \\
6 & M3 & 17 & Very High \\
7 & L1 & 14 & High \\
8 & L2 & 14 & High \\
9 & L3 & 15 & High \\
\hline \multicolumn{7}{c}{ Average } & 16,7 & Very Hight \\
\hline
\end{tabular}

The data verification of the questionnaire is with a high academic ability $(\mathrm{H})$. The data observations of learning activities and interview results through technical triangulation showed that students with high academic abilities $(\mathrm{H})$. Students were not nervous, did not panic, and did not afraid when doing physics experiments on PhET Simulation when discussing experimental results.

The data verification of students' questionnaire is a moderate academic ability (M). The data from observations of learning activities and interview results through technical triangulation showed that students with moderate academic ability (M) were not nervous when conducting experiments, did not panic when asked by the teacher to display experiments. Physics in PhET Simulation that they are working on do not panic if other students are faster in completing physics experiments in PhET Simulation and are not afraid to express their opinions during the discussion of experimental results. However, students with moderate academic ability $(\mathrm{M})$ panic if they have problems when doing physics experiments on PhET Simulation.

The data verification of students' questionnaire is a low academic ability $(\mathrm{L})$. The data from observations of learning activities and interview results through technical triangulation shows that students with low academic abilities (L) are not nervous when conducting experiments and do not panic if other students are faster. In completing physics experiments on PhET Simulation and not afraid to express their opinion during the discussion of experimental results. However, students with a low academic ability (L) panicked when they had problems doing physics experiments on PhET Simulation and when asked by the teacher to perform physics experiments on the PhET Simulation they were doing.

\section{Description of students' learning motivation towards the use of PhET Simulation in terms of students' self-efficacy and anxiety levels}

Students' motivation towards using PhET Simulation in online learning physics in class XI IPA SMA Terpadu Wira Bhakti Gorontalo in terms of students' self-efficacy and anxiety levels can be seen in Table 6.

Table 6. Student Learning Motivation in terms of the level of Self-Efficacy and Student Anxiety

\begin{tabular}{cccc}
\hline No. & Aspect & Score & Category \\
\hline 1 & Self-Efficacy & 17,1 & Very High \\
2 & Anxiety & 16,7 & Very High \\
& Average & 16,9 & Very Hight \\
\hline
\end{tabular}

Based on Table 6, it can be seen that students' motivation in terms of the level of self-efficacy and student anxiety is categorized as very high. The motivation to learn will be stronger if students have self-efficacy because belief in their abilities can motivate them to act more effectively in determining the steps that will be faced to complete a task [12]. A person with a high level of self-efficacy does not give up easily and is persistent in doing his study assignments. He has confidence in himself to be increasingly motivated to complete learning tasks and take responsibility for it [20]. Factors that trigger anxiety in students are the demands of learning achievement targets that are too high, the learning atmosphere is not conducive, giving complex learning assignments, and fear of assessment of learning outcomes [21]. Anxiety refers to an emotional state such as feeling depressed when experiencing difficulties characterized by the emergence of worry, fear, and concern in certain situations. Still, if the individual eliminates anxiety, that feeling will become a motivator to do something [22]. Negative emotions can reduce the quality of student learning motivation which includes feelings of excessive worry and fear, fear of failure, and fear of punishment [13].

The use of PhET Simulation in physics online learning in class XI IPA SMA Terpadu Wira Bhakti Gorontalo turned out to have a good influence on students' learning motivation with a very high level of learning motivation on a review of students' selfefficacy and anxiety in the learning process. The study results are supported by previous research [23], which revealed that $\mathrm{PhET}$ facilitates both teachers and students in the learning process to foster learning motivation for students. In addition, other studies [24] also showed that PhET Interactive Simulation affects learning motivation and understanding of science concepts. 


\section{CONCLUSIONS}

Based on the results of a review of selfefficacy, The students become motivated in learning physics because of the use of PhET Simulation in online physics learning in class XI IPA SMA Terpadu Wira Bhakti Gorontalo with a very high level of learning motivation. In addition, the results of a review of anxiety showed that students became motivated in learning physics because of the use of PhET Simulation in online learning physics in class XI IPA SMA Terpadu Wira Bhakti Gorontalo with a very high level of learning motivation. Thus, it can be concluded that students become motivated to understand the use of PhET Simulation in online learning physics class XI IPA SMA Terpadu Wira Bhakti Gorontalo in terms of self-efficacy. Student anxiety is categorized as very high.

\section{REFERENCES}

[1]. Handarini, O. I., \& Wulandari, S. S. (2020). Pembelajaran Daring Sebagai Upaya Study from Home (SFH) Selama Pandemi Covid 19. Jurnal Pendidikan Administrasi Perkantoran, 8(3), 496-503.

[2]. Awalia, D. H., Dadi S., \& Kusmiyati. (2021). Analysis of e-Learning Problems During Covid19 Pandemic. Jurnal Pijar Mipa, 16(5), 631-635.

[3]. Sadikin A., \& Hamidah, A. (2020). Pembelajaran Daring di Tengah Wabah Covid19. Jurnal Ilmiah Pendidikan Biologi (BIODIK), 6(2), 214-224.

[4]. Oknisih, N., \& Sutoyo, S. (2019). Penggunaan APLEN (Aplikasi Online) Sebagai Upaya Kemandirian Belajar Siswa. In Seminar Nasional Pendidikan Dasar, 1(1), 477-483.

[5]. Nengrum, T., A., Najamuddin, P. S., \& Muhammad, N., I. (2021). Kelebihan dan kekurangan Pembelajaran Luring dan Daring dalam Pencapaian Kompetensi Dasar Kurikulum Bahasa Arab di Madrasah Ibtidaiyah 2 Kabupaten Gorontalo. Jurnal Pendidikan, 30(1).

[6]. Hastuti, W. B. (2021). Meretas Motivasi Belajar Peserta Didik di Era Pandemi Melalui Video Virtual Laboraty. Jurnal Kediklatan Balai Diklat Keagamaan Jakarta, 2(1), 33-39.

[7]. Wieman, C. E., Adams, W., Loeblein, P., \& Perkins, K. K. (2020). Teaching Physics Using PhET Simulations. The Physics Teacher, 48(4), 225-227. https://doi.org/10.1119/1.3361987.

[8]. Prawira, P. A. (2017). Psikologi Pendidikan dalam Perspektif Baru. Yogyakarta: Ar-Ruzz Media.

[9]. Sidik, Z., \& Sobandi, A. (2018). Upaya Meningkatkan Motivasi Belajar Siswa Melalui Kemampuan Komunikasi Interpersonal Guru. Jurnal Pendidikan Manajemen Perkantoran, 3(2), 190-198.

[10]. Dimyati, \& Mudjiono. (2013). Belajar dan Pembelajaran. Jakarta: Rineka Cipta.

[11]. Glynn, S. M., \& Koballa Jr., T. R. (2006). Motivation to Learn in College Science. In J. J.
Mintzes \& W. H. Leonard (Eds.), Handbook of College Science Teaching (pp. 25-31). Arlington, Virginia: National Science Teachers Association Press.

[12]. Oktaverina, I., \& Nashori, H. F. (2015). Efektivitas Pelatihan Efikasi Diri dalam Meningkatkan Motivasi Belajar Matematika Siswa Sekolah Menengah Pertama. Jurnal Psikologi TALENTA, 1(1), 1-14.

[13]. Vivin, Marpaung, W., \& Manurung, Y. S. (2019). Kecemasan dan Motivasi Belajar. Jurnal Psikologi Indonesia, 8(2), 240-257.

[14]. Widodo, S. A., Laelasari, Sari, R. M., Nur, I. R. D., \& Putrianti, F. G. (2017). Analisis Faktor Tingkat Kecemasan, Motivasi dan Prestasi Belajar Mahasiswa. Jurnal Taman Cendekia, 1(1), 67-77.

[15]. Sugiyono. (2013). Metode Penelitian Kuantitatif, Kualitatif, Dan $R \& D$. Bandung: Alfabeta

[16]. Satori, D., \& Komariah, A. (2010). Metodologi Penelitian Kualitatif. Bandung: Alfabeta.

[17]. Azwar, S. (2009). Penyusunan Skala Psikologi. Yogyakarta: Pustaka Pelajar.

[18]. Suryaningsih, I., \& Rahim, R. A. (2019). Efektivitas Pelatihan Efikasi Diri dalam Meningkatkan Motivasi Belajar Siswa Kelas X SMA Insan Cendekia Syech Yusuf Kab. Goa. Jurnal Ilmiah Pendidikan Matematika EQUALS, 2(2), 85-91.

[19]. Santrock, J. W. (2011). Educational Psychology (5th ed.). New York: McGraw-Hill.

[20]. Putri, K. A. R. D., \& Rustika, I. M. (2018). Peran Kemandirian dan Efikasi Diri Terhadap Motivasi Berprestasi pada Siswa Kelas Unggulan SMA Dwijendra Denpasar. Jurnal Psikologi Udayana, 5(1), 12-22.

[21]. Putranta, H., \& Jumadi. (2019). Physics Teacher Efforts of Islamic High School in Yogyakarta to Minimize Students' Anxiety When Facing the Assessment of Physics Learning Outcomes. Journal for the Education of Gifted Young Scientists, 7(2), 119-136.

[22]. Yanti, S., Erlamsyah, Zikra, \& Ardi, Z. (2013). Hubungan antara Kecemasan dalam Belajar dengan Motivasi Belajar Siswa. Jurnal Ilmiah Konseling, 2(1), 283-288.

[23]. Khaerunnisak. (2018). Peningkatan Pemahaman Konsep dan Motivasi Belajar Siswa Melalui Simulasi Physic Education Tchnology (PhET). Jurnal Penelitian Pendidikan IPA, 4(2), 7-12.

[24]. Rahayu, C. D., \& Sartika, S. B. (2020). Students Learning Motivation and Concepts Understanding of Science through the Use of PhET Interaktive SimulationScience Education Journal, 4(1), 63-68. 